\title{
Country-level climate-crop yield relationships and the impacts of climate change on food security
}

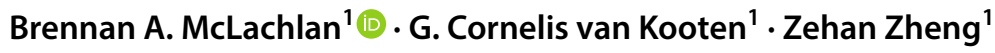

Received: 3 April 2020 / Accepted: 26 August 2020 / Published online: 9 September 2020

(c) Springer Nature Switzerland AG 2020

\begin{abstract}
Projected climate change has stimulated increasing interest in the interactive effects between carbon dioxide $\left(\mathrm{CO}_{2}\right)$ and temperature on crop yields. Crop yields are anticipated to decline if Earth continues to warm but increase as $\mathrm{CO}_{2}$ concentration rises. These two factors tend to work in opposite directions, and the interactive effect is not yet clear. There are also significant concerns that climate change is going to undermine global food security. Our purpose is to examine the quantitative relationship between $\mathrm{CO}_{2}$ and temperature on crop yields and to explore food security or insecurity in the presence of climate change. To do so, we perform a historical analysis on the crop yield trends in 57 selected countries from 1961 to 2013 on a yearly basis employing a fixed-effects panel regression model. The model is based on $\mathrm{CO}_{2}$ levels measured at Mauna Loa, Hawaii, and weighted-average temperatures in each country in corresponding years. We also incorporate other socio-economic factors, including purchasing power parity adjusted gross domestic product (PPP GDP) and education levels measured by Human Capital Index ( $\mathrm{HCl}$ ), that might affect crop yields. In addition, we control for other factors such as technological changes that contribute to increased yields. We find mixed evidence regarding $\mathrm{CO}_{2}$-fertilization and rising temperatures where some crops benefits and others are damaged. We identify four tipping points for $\mathrm{CO}_{2}$ beyond which $\mathrm{CO}_{2}$ is no longer beneficial for wheat, maize, rapeseed, and rice, where maize is expected to sustain benefits from $\mathrm{CO}_{2}$-fertilization up until $800 \mathrm{ppm}$. We also find that rice is damaged by rising temperatures beyond $44^{\circ} \mathrm{C}$.
\end{abstract}

Keywords Food security $\cdot \mathrm{CO}_{2}$-fertilization $\cdot$ Heat and crop yields $\cdot$ Regression analysis

JEL classification $013 \cdot \mathrm{Q} 51 \cdot \mathrm{Q} 54$

\section{Introduction}

Adverse weather is perhaps the greatest risk to crop production, which makes the agricultural sector particularly vulnerable to climate change [1,20]. With the adoption of the Paris Agreement in 2015 at COP21 of the UN's Framework Convention on Climate Change (UNFCCC) and the subsequent special report on the need to prevent the globe's mean surface temperature from exceeding $1.5^{\circ} \mathrm{C}$ [13], there is increasing concern about future food insecurity. The Paris Agreement recognizes "the fundamental priority of safeguarding food security and ending hunger, and the particular vulnerabilities of food production systems to the adverse impacts of climate change." ${ }^{\prime 1}$ The main questions of concern to be addressed in this study are the following: Are rising levels of atmospheric $\mathrm{CO}_{2}$ and projected warming a threat to food security? Does

\footnotetext{
1 See https://unfccc.int/process-and-meetings/the-paris-agree ment/the-paris-agreement [accessed 10 December 2019]. To illustrate the concern about food security, Porter et al. [26] found that the five IPCC Assessment Reports to date show "a worrying change in food production for a range of scenarios of climate change, locations, crops, and levels of adaptation" (p. 681).
}

Brennan A. McLachlan, brennan9@uvic.ca| 'Department of Economics, University of Victoria, Victoria, Canada. 
Fig. 1 Historical Representative Global Crop Yields Source: FAO [9] Created using R Version 1.1.463

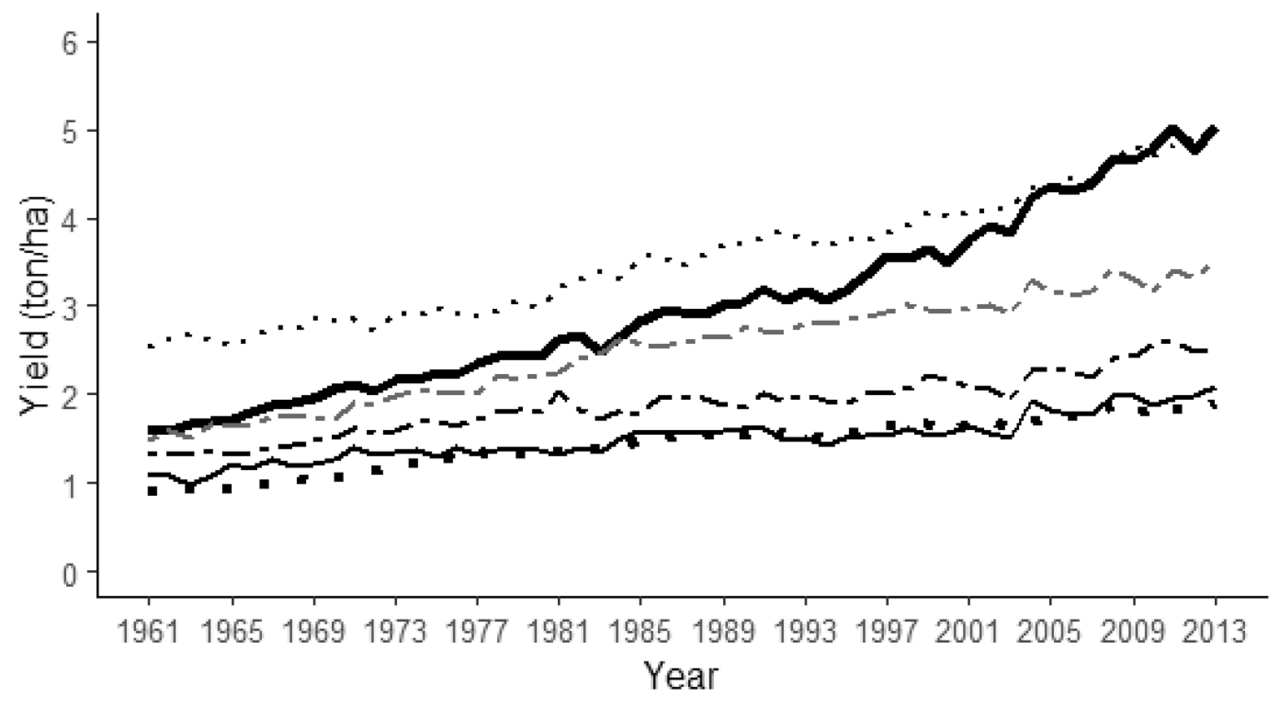

Legend - Maize $\cdots$ Rapeseed - ' Sorghum the $\mathrm{CO}_{2}$-fertilization effect offset potential declines in crop yields associated with increasing temperatures?

It is generally agreed that a greater concentration of atmospheric $\mathrm{CO}_{2}$ can result in a fertilization effect that increases crop yields [21,35], but it is also the case that, while more heat (higher temperatures) can benefit plant growth, yields will eventually fall as temperatures continue to rise. It is clear that the atmospheric concentration of $\mathrm{CO}_{2}$ has been increasing. Based on continuous measurements at Mauna Loa, Hawaii $[6,28]$, atmospheric $\mathrm{CO}_{2}$ has risen from some 316 parts per million by volume (ppm) in 1959 to $412 \mathrm{ppm}$ in 2019. Projections indicate that the $\mathrm{CO}_{2}$ concentration could increase to some 500 to 1,300 ppm by 2100 , depending on which of the several the Representative Concentration Pathways (RCP) that is chosen [29], with the IPCC projecting an associated increase in global mean surface temperatures of $2.6-4.8^{\circ} \mathrm{C}$ by 2100 [12]. The RCPs are based on integrated assessment models (IAMs) that project future population, economic activity, energy use, land-use patterns, technology, and climate policy. Four RCP scenarios are then used in global climate models to project potential warming. RCP2.6 assumes that emissions of greenhouse gases, aggregated to a carbon-dioxide equivalent (hereafter simply $\mathrm{CO}_{2}$ ), will peak between 2010 and 2020, declining substantially thereafter. Under RCP4.5, emissions peak about 2040 and decline thereafter; under RCP6.0, they peak in 2080 and then decline; and, under RCP8.5, emissions are assumed to increase throughout the twenty-first century so that the atmospheric concentration of $\mathrm{CO}_{2}$ exceeds 1300 ppm [23].

Estimating a correct relationship between crop yields and climate variables is a crucial first step in addressing questions about food security. The purpose of the current study, therefore, is to examine the effect that changes in atmospheric $\mathrm{CO}_{2}$ and temperature have had on crop yields in the past, and what this might imply for the future. Based on our estimated relationships, we attempt to answer the question of whether food insecurity is an imminent threat.

We focus on six main cereal crops: wheat, rice, maize, rapeseed (canola), soybean and sorghum. Wheat, rice and maize are the most important crops accounting for some $60 \%$ of the globe's production of cereals [30]. Rice is a staple food for more than half of the world's population [10], although maize is the main staple in many regions of the world. Wheat is the most important cereal grain in temperate climates [8]. Soybean is an important crop because it accounts for $29.7 \%$ of the world's processed vegetable oils [11], followed by rapeseed/canola [9]. ${ }^{2}$ Finally, sorghum is an important crop, partly because it is drought-resistant and able to withstand periods of waterlogging; thus, it is uniquely adapted to Africa's climate but it is also important in countries such as the U.S. where weather in some regions is less suited to other crops [36]. Because of its resilience, sorghum will continue to play an essential role in the future as climate change continues (Fig. 1).

In Fig. 2, we plot the average of the annual yields of the top twenty producers of each crop; the data indicate that yields of all six crops in the major producing countries have increased significantly since 1961. Then, we use the Berkeley Earth Surface Temperature (BEST) data series

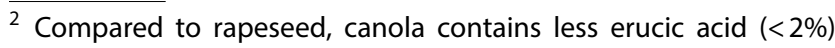
and lower levels of glucosinolates.
} 
Fig. 2 Average Representative Temperatures by Continent, 1961-2013. [3] Source: Berkeley Earth. Creating Using R Version 1.1.463

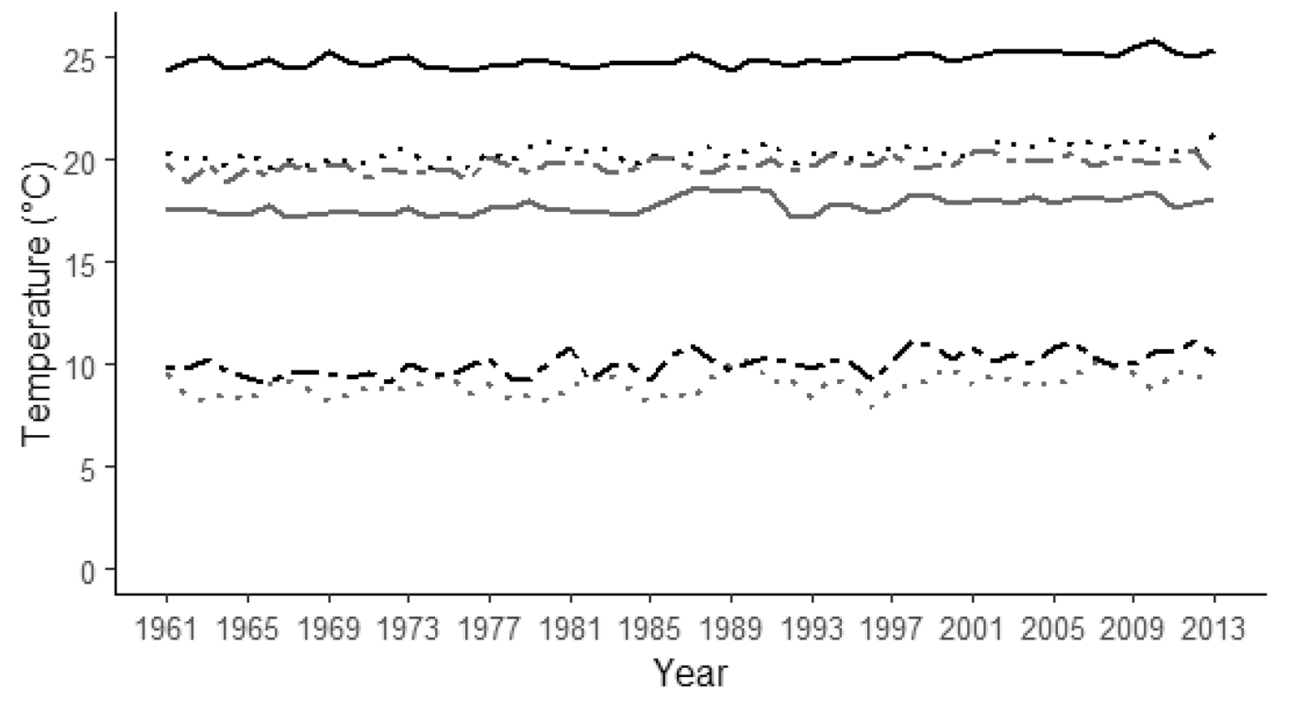

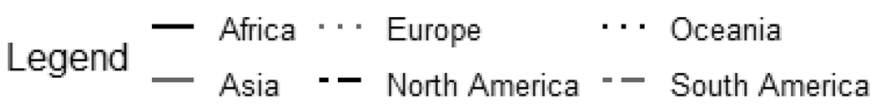

to construct historical annual temperatures by crop and continent [3], spatially-weighted by a continent's countries that are in the global top-twenty producing countries of the crop in question. Temperatures are provided on a continent basis for each crop in Fig. 3 for the period 1961-2018. Notice that temperatures in Africa are on average higher than those elsewhere. Further, the annual variation in temperatures exceeds the overall increase in temperatures over the period. Indeed, in some cases, there appears to be no trend in average BEST temperatures. This is an artefact of the method used to calculate the temperatures: the average surface temperatures of the top 20 producing countries of each crop are employed. This implies that the countries comprising the spatially-weighted continental averages change from one crop to the next and perhaps even from one year to the next.

The yield response of the six crops to projected changes in atmospheric $\mathrm{CO}_{2}$ and temperature is indicative of potential future food insecurity. Using FAO crop yield data, we investigate the impact of $\mathrm{CO}_{2}$ and temperature on crop yields and develop statistical methods to determine how past yields have responded to increases in atmospheric $\mathrm{CO}_{2}$ and climate/weather variables. The estimated relationships are then used to determine the yield response to changes in projected $\mathrm{CO}_{2}$ and temperatures (heat).

The extent to which climate change impacts food security is ambiguous and varies among differing local climates. Developing countries are the least able to adapt to climate change and the agricultural sector in those countries is expected to be impacted more than that in developed countries. Developed countries are simply better able to adjust agricultural output in response to climate change through the use of irrigation, new crops or enhanced crop varieties (including genetically-modified varieties), information technology (e.g., drones that target specific weed infestations as opposed to broadcasting herbicides), improved farm management techniques, et cetera. Developed countries simply employ more inputs, more intensively than can farmers in developing countries. The current study takes the development level of each country across periods into account and controls for its effect. Consequently, the results will be useful for further analysis of crop-planting choices, policymaking, et cetera, in countries with different backgrounds.

Considerable research in the past was devoted to investigating the impact of temperature and $\mathrm{CO}_{2}$ on crop yields. Schlenker and Roberts concluded that [32], for maize, soybean and cotton, crop growth increases gradually with temperatures up to 29 to 32 degrees Celsius $\left({ }^{\circ} \mathrm{C}\right)$, depending on the crop, and then decreases sharply for all three crops, ceteris paribus.

Lobell and Field conducted a global scale [17], climatecrop yield study based on FAO data from 1961 to 2002. They investigated the statistical relationship between climate and crop yields, focusing on wheat, rice, maize, soy, barley and sorghum. The researchers employed modeled gridded monthly temperature and rainfall data from the Climate Research Unit at the University of East Anglia. As a dependent variable in their linear regressions, Lobell and Field used first differences in yield, with minimum and maximum temperatures, and precipitation, as explanatory variables. The use of first differences is to minimize the influence of slowly changing factors such as crop management. However, they did not consider the impact 
of $\mathrm{CO}_{2}$ fertilization and adaptation measures taken by farmers that could potentially offset the negative effects of higher temperatures. Thus, their study results might be considered an upper bound on the potential negative impacts of climate change on crop yields. They found that at least $29 \%$ of the variance in year-to-year yield changes was explained by the predictors for all crops, and it was very likely that the global warming from 1981-2002 offset some of the yield gains from technological advances, rising $\mathrm{CO}_{2}$, and other non-climatic factors.

Subsequently, Lobell et al. [18] examined the impact of climate change on crop yields at the country level for the period 1980-2008. They incorporated data on monthly temperature and precipitation, crop production, crop locations, and growing seasons and used panel analyses of maize, wheat, rice and soybean for all countries. They found that climate impacts often exceeded $10 \%$ of the rate of yield change, which indicated that climate changes were already exerting a considerable drag on yield growth. Like the earlier study, Lobell et al. [18] did not consider the impact of $\mathrm{CO}_{2}$ fertilization and other factors, such as technological advances, in their statistical models.

Challinor et al. [4] conducted a meta-analysis of 1048 observations from 66 studies to determine the separate impacts of adaptation, change in temperature, change in $\mathrm{CO}_{2}$, and change in precipitation on crop yields in tropical and temperate regions. They concluded that, if farmers adapted to the changed climate conditions, wheat, maize, and rice yields in temperate regions would increase as a result of higher temperatures, ceteris paribus, but production of maize and wheat would be adversely affected by higher temperatures in the tropics. Importantly, however, the analysis showed that, while rice yields in the tropics would be unaffected by temperature increases between $0{ }^{\circ} \mathrm{C}$ and $3{ }^{\circ} \mathrm{C}$, rice yields would increase by $10 \%$ or more if temperatures rose by upwards of $5^{\circ} \mathrm{C}$, ceteris paribus. Indeed, temperature was the dominant factor explaining changes in crop yields, with precipitation and $\mathrm{CO}_{2}$ fertilization playing a minor albeit yield-enhancing role (contributing less than $15 \%$ of the overall change in crop yields). Similar results were reported by Moore et al. [24], who also conducted a meta-analysis, but with 1010 point estimates from 56 studies.

Finally, the U.S. National Climate Assessment report [39] projects mid-century (2036-2065) yields of commodity crops to decline by " $5 \%$ to over $25 \%$ below extrapolated trends broadly across the region for corn, and more than $25 \%$ for soybeans in the southern half of the region." It is important to notice that the report does not suggest that crop yields will fall; rather, U.S. crop yields are expected to continue trending upwards, but productivity growth will be below what it would be in the absence of climate change.
The current investigation extends previous studies by considering temperature, $\mathrm{CO}_{2}$, technological advances, and other adaptations in our regression models, thus presenting a clearer picture of future food security. In particular, we examine the inferred impact of climate change on observed yield trends at the country level for the period 1961-2013 (the latest year for which complete FAO data were available). We also include spatially-weighted temperatures at country levels, and the interaction effects between $\mathrm{CO}_{2}$ and temperature.

\section{Methods}

Historical data on crop yields from the Food and Agriculture Organization (FAO) of the United Nations are used to examine the impact of $\mathrm{CO}_{2}$ and temperature on crop yields across countries $[9,37]$. We employ crop yield data from the top twenty producers of each crop along with surface temperature and $\mathrm{CO}_{2}$ data, and the socio-demographic characteristics of each country. A panel regression model is developed to observe variations in crop yields within periods and between countries. Our database consists of 57 countries for the period 1961-2013 and six crops (number of observations in parentheses): wheat (2096), rice (2013), soybean (1932), maize (2307), rapeseed (1,395), and sorghum (1720).

\subsection{Data collection}

Yields are spread extensively over the six crops and the different countries producing those crops. There is a lot of overlap in the top twenty producing countries-countries that are top producers of any given crop are likely to be a top producer of another crop as well. A list of countries broken down by crop is provided in Table 1, with summary statistics for all six crops presented in Table 2 .

We employ spatially-weighted, location-specific temperature data from the BEST database [3]. For smaller countries, we use the national average temperature, but, for larger countries such as Canada, China, the U.S. and Brazil, we employ production-weighted temperatures of the respective regions within which each crop is grown. For example, in Canada, wheat is grown in the prairies and central provinces; therefore, it makes sense to use production-weighted averaged temperatures from a select number of weather stations within these regions rather than a national average. Production maps provided by the United States Department of Agriculture [38] are used to identify the proportion of production by area of each crop. In most cases, total production identified by the USDA does not sum up to $100 \%$. In these cases, total production is adjusted to the sum of production percentages indicated by the production map, with the production of each region adjusted accordingly. For 
Table 1 List of Countries and Data

\begin{tabular}{|c|c|c|c|c|c|c|}
\hline \multirow[t]{2}{*}{ Country } & \multicolumn{6}{|c|}{ Number of observations/Time periods (Frequency, \%) } \\
\hline & Wheat & Rice & Maize & Soybean & Sorghum & Rapeseed \\
\hline Argentina & $53(2.53)$ & $53(2.63)$ & $53(2.25)$ & $53(2.61)$ & $53(2.91)$ & $53(3.43)$ \\
\hline Australia & $53(2.53)$ & $53(2.63)$ & $53(2.25)$ & $53(2.61)$ & $53(2.91)$ & $46(2.98)$ \\
\hline Bangladesh & $53(2.53)$ & $53(2.63)$ & $53(2.25)$ & $53(2.61)$ & $53(2.91)$ & $53(3.43)$ \\
\hline Brazil & $53(2.53)$ & $53(2.63)$ & $53(2.25)$ & $53(2.61)$ & $53(2.91)$ & $34(2.20)$ \\
\hline Burkina Faso & - & $53(2.63)$ & $53(2.25)$ & $31(1.53)$ & $53(2.91)$ & - \\
\hline Cambodia & - & $44(2.19)$ & $44(1.87)$ & $44(2.17)$ & - & - \\
\hline Cameroon & $38(1.81)$ & $53(2.63)$ & $53(2.25)$ & $36(1.77)$ & $53(2.91)$ & - \\
\hline Canada & $53(2.53)$ & - & $53(2.25)$ & $53(2.61)$ & - & $53(3.43)$ \\
\hline China & $53(2.53)$ & $53(2.63)$ & $53(2.25)$ & $53(2.61)$ & $53(2.91)$ & $53(3.43)$ \\
\hline Czechia & $21(1.00)$ & - & $21(0.89)$ & $21(1.03)$ & - & $21(1.36)$ \\
\hline Denmark & $53(2.53)$ & - & $53(2.25)$ & - & - & $53(3.43)$ \\
\hline Egypt & $53(2.53)$ & $53(2.63)$ & $53(2.25)$ & $42(2.07)$ & $53(2.91)$ & - \\
\hline Ethiopia & $53(2.53)$ & $21(1.04)$ & $53(2.25)$ & $53(2.61)$ & $53(2.91)$ & $53(3.43)$ \\
\hline France & $53(2.53)$ & $53(2.63)$ & $53(2.25)$ & $41(2.02)$ & $53(2.91)$ & $53(3.43)$ \\
\hline Germany & $53(2.53)$ & - & $53(2.25)$ & $25(1.23)$ & - & $53(3.43)$ \\
\hline Hungary & $44(2.10)$ & $44(2.19)$ & $44(1.87)$ & $41(2.02)$ & $44(2.41)$ & $44(2.85)$ \\
\hline India & $53(2.53)$ & $53(2.63)$ & $53(2.25)$ & $53(2.61)$ & $53(2.91)$ & $53(3.43)$ \\
\hline Iran & $53(2.53)$ & $53(2.63)$ & $53(2.25)$ & $53(2.61)$ & - & $53(3.43)$ \\
\hline Italy & $53(2.53)$ & $53(2.63)$ & $53(2.25)$ & $53(2.61)$ & $53(2.91)$ & $53(3.43)$ \\
\hline Japan & $53(2.53)$ & $53(2.63)$ & $53(2.25)$ & $53(2.61)$ & $32(1.76)$ & $53(3.43)$ \\
\hline Kazakhstan & $22(1.05)$ & 22 (1.09) & $22(0.93)$ & $22(1.08)$ & $22(1.21)$ & $22(1.42)$ \\
\hline Lithuania & $22(1.05)$ & - & $22(0.93)$ & - & - & $22(1.42)$ \\
\hline Madagascar & $38(1.81)$ & $53(2.63)$ & $53(2.25)$ & 39 (1.92) & $53(2.91)$ & - \\
\hline Mali & $53(2.53)$ & $53(2.63)$ & $53(2.25)$ & $53(2.61)$ & $53(2.91)$ & - \\
\hline Mexico & $53(2.53)$ & $53(2.63)$ & $53(2.25)$ & $53(2.61)$ & $53(2.91)$ & $53(3.43)$ \\
\hline Myanmar & $52(2.48)$ & $52(2.58)$ & $52(2.21)$ & $52(2.56)$ & $52(2.85)$ & - \\
\hline Nepal & $53(2.53)$ & $53(2.63)$ & $53(2.25)$ & $53(2.61)$ & - & - \\
\hline Niger & $53(2.53)$ & $53(2.63)$ & $53(2.25)$ & - & $53(2.91)$ & - \\
\hline Nigeria & $53(2.53)$ & $53(2.63)$ & $53(2.25)$ & $53(2.61)$ & $53(2.91)$ & - \\
\hline Pakistan & $53(2.53)$ & $53(2.63)$ & $53(2.25)$ & $53(2.61)$ & $53(2.91)$ & $53(3.43)$ \\
\hline Paraguay & $53(2.53)$ & $53(2.63)$ & $53(2.25)$ & $53(2.61)$ & $53(2.91)$ & $53(3.43)$ \\
\hline Philippines & - & $53(2.63)$ & $53(2.25)$ & $53(2.61)$ & $44(2.41)$ & - \\
\hline Poland & $44(2.10)$ & - & $44(1.87)$ & $44(2.17)$ & - & $44(2.85)$ \\
\hline Romania & $53(2.53)$ & $53(2.63)$ & $53(2.25)$ & $53(2.61)$ & $53(2.91)$ & $53(3.43)$ \\
\hline Russia & $24(1.15)$ & $24(1.19)$ & $24(1.02)$ & $24(1.18)$ & $24(1.32)$ & $24(1.55)$ \\
\hline Serbia & $8(0.38)$ & - & $8(0.34)$ & $8(0.39)$ & $8(0.44)$ & $8(0.52)$ \\
\hline Slovakia & $21(1.00)$ & - & $21(0.89)$ & $21(1.03)$ & $21(1.15)$ & $21(1.36)$ \\
\hline South Africa & $53(2.53)$ & $53(2.63)$ & $53(2.25)$ & $53(2.61)$ & $53(2.91)$ & $53(3.43)$ \\
\hline South Korea & $53(2.53)$ & $53(2.63)$ & $53(2.25)$ & $53(2.61)$ & $53(2.91)$ & $53(3.43)$ \\
\hline Spain & $53(2.53)$ & $53(2.63)$ & $53(2.25)$ & $44(2.17)$ & $53(2.91)$ & $45(2.91)$ \\
\hline Sri Lanka & - & $53(2.63)$ & $53(2.25)$ & $53(2.61)$ & $53(2.91)$ & - \\
\hline Sudan & $44(2.10)$ & $44(2.19)$ & $44(1.87)$ & - & $44(2.41)$ & -- \\
\hline Sweden & $53(2.53)$ & - & - & - & - & $53(3.43)$ \\
\hline Thailand & $28(1.34)$ & $53(2.63)$ & $53(2.25)$ & $53(2.61)$ & $53(2.91)$ & - \\
\hline Turkey & $53(2.53)$ & $53(2.63)$ & $53(2.25)$ & $53(2.61)$ & $53(2.91)$ & $53(3.43)$ \\
\hline Ukraine & $22(1.05)$ & $22(1.09)$ & $22(0.93)$ & $22(1.08)$ & $22(1.21)$ & $22(1.42)$ \\
\hline United Kingdom & $53(2.53)$ & - & $11(0.47)$ & - & - & $53(3.43)$ \\
\hline United States & $53(2.53)$ & $53(2.63)$ & $53(2.25)$ & $53(2.61)$ & $53(2.91)$ & $27(1.75)$ \\
\hline Uruguay & $53(2.53)$ & $53(2.63)$ & $53(2.25)$ & $53(2.61)$ & $53(2.91)$ & $53(3.43)$ \\
\hline
\end{tabular}


Table 1 (continued)

\begin{tabular}{|c|c|c|c|c|c|c|}
\hline \multirow[t]{2}{*}{ Country } & \multicolumn{6}{|c|}{ Number of observations/Time periods (Frequency, \%) } \\
\hline & Wheat & Rice & Maize & Soybean & Sorghum & Rapeseed \\
\hline Vietnam & - & $44(2.19)$ & $44(1.87)$ & $44(2.17)$ & - & - \\
\hline Yemen & 25 (1.19) & - & $25(1.06)$ & - & $25(1.37)$ & - \\
\hline Total & $\begin{array}{l}2096 \\
(100.00)\end{array}$ & $\begin{array}{l}2013 \\
(100.00)\end{array}$ & $\begin{array}{l}2356 \\
(100.00)\end{array}$ & $\begin{array}{l}2032 \\
(100.00)\end{array}$ & $\begin{array}{l}1822 \\
(100.00)\end{array}$ & $\begin{array}{l}1546 \\
(100.00)\end{array}$ \\
\hline
\end{tabular}

Table 2 Summary Statistics for Six Crops

\begin{tabular}{|c|c|c|c|c|c|c|c|c|}
\hline \multirow[t]{2}{*}{ Variables } & \multicolumn{4}{|l|}{ Wheat } & \multicolumn{4}{|l|}{ Maize } \\
\hline & mean & sd & $\min$ & $\max$ & mean & sd & $\min$ & $\max$ \\
\hline Yield (ton/ha) & 2.631 & 1.672 & 0.314 & 8.281 & 3.098 & 2.311 & 0.261 & 11.37 \\
\hline Temperature $\left({ }^{\circ} \mathrm{C}\right)$ & 16.53 & 7.569 & -2.042 & 30.13 & 18.64 & 7.666 & -2.158 & 30.13 \\
\hline $\mathrm{CO}_{2}(\mathrm{ppm})$ & 354.1 & 23.42 & 317.6 & 396.5 & 353.5 & 23.50 & 317.6 & 396.5 \\
\hline Human Capital index & 2.200 & 0.813 & 1.009 & 3.726 & 2.071 & 0.780 & 1.007 & 3.718 \\
\hline \multirow[t]{3}{*}{ Real GDP per capita ${ }^{a}$} & 11,368 & 11,251 & 425.9 & 51,548 & 9,152 & 10,340 & 425.9 & 51,548 \\
\hline & \multicolumn{4}{|c|}{ Soybean } & \multicolumn{4}{|c|}{ Rapeseed/Canola } \\
\hline & mean & sd & $\min$ & $\max$ & mean & sd & $\min$ & $\max$ \\
\hline Yield (ton/ha) & 1.502 & 0.757 & 0.175 & 5.947 & 1.567 & 0.802 & 0.202 & 4.287 \\
\hline Temperature $\left({ }^{\circ} \mathrm{C}\right)$ & 18.22 & 7.486 & -2.433 & 30.13 & 13.33 & 6.701 & -2.071 & 26.82 \\
\hline $\mathrm{CO}_{2}(\mathrm{ppm})$ & 355.2 & 23.22 & 317.6 & 396.5 & 356.4 & 23.50 & 317.6 & 396.5 \\
\hline Human Capital Index & 2.140 & 0.758 & 1.013 & 3.718 & 2.524 & 0.739 & 1.016 & 3.726 \\
\hline \multirow[t]{3}{*}{ Real GDP per capita ${ }^{a}$} & 9837 & 10,660 & 425.9 & 51,548 & 14,972 & 11,723 & 528.1 & 51,548 \\
\hline & \multicolumn{4}{|l|}{ Rice } & \multicolumn{4}{|c|}{ Sorghum } \\
\hline & mean & sd & $\min$ & $\max$ & mean & sd & $\min$ & $\max$ \\
\hline Yield (ton/ha) & 3.589 & 1.918 & 0.481 & 10.39 & 1.960 & 1.484 & 0.126 & 7.600 \\
\hline Temperature $\left({ }^{\circ} \mathrm{C}\right)$ & 20.19 & 6.246 & 4.697 & 30.13 & 20.00 & 7.008 & 4.697 & 30.13 \\
\hline $\mathrm{CO}_{2}(\mathrm{ppm})$ & 352.8 & 23.40 & 317.6 & 396.5 & 353.7 & 23.7 & 317.6 & 396.5 \\
\hline Human capital index & 1.971 & 0.712 & 1.007 & 3.718 & 2.018 & 0.739 & 1.007 & 3.718 \\
\hline Real GDP per capita ${ }^{a}$ & 8,036 & 9612 & 425.9 & 51,548 & 8,341 & 9684 & 425.9 & 51,548 \\
\hline
\end{tabular}

${ }^{a}$ Measured in \$U.S.2011 millions adjusted for Purchasing Power Parity (PPP). See text for more information

example, $60 \%$ of soybeans in Canada are produced in Ontario, $23 \%$ in Manitoba, and $16 \%$ in Quebec, with $1 \%$ of soybeans produced elsewhere in Canada. As the 1\% produced outside the main provinces is ignored, the weights in the main producing provinces are adjusted slightly upwards so the main producing provinces are assumed to account for $100 \%$ of production.

The Mauna Loa annual $\mathrm{CO}_{2}$ data are from the Earth System Research Laboratory of the National Oceanic and Atmospheric Administration (NOAA) [6]. We assume that atmospheric $\mathrm{CO}_{2}$ is uniformly distributed and does not vary across countries. This is a strong assumption that is the result of data limitations. Yet we believe the model still provides useful insights regarding the inferred impact of climate change on crop yield trends. $\mathrm{CO}_{2}$ measurements are affected by the occasional volcanic eruption (e.g., eruptions in Hawaii in 1975 and 1984). These are addressed by the Mauna Loa Observatory by accounting for wind direction and flagging data when the variability of a 10-min interval was greater than that of a reference plume, leading to some indicator that a volcanic plume had affected the measurements [31]. These atypical fluctuations are accounted for in the resulting data. ${ }^{3}$

Finally, we make use of the Penn World Table (PWT) version 9.1 database from the University of Groningen [7]. The PWT is a database that summarizes a group of sociodemographic characteristics, including the relative inputs, outputs and productivity of 182 countries for the period 1950 through 2017. We make use of the Purchasing Power Parity adjusted Gross Domestic Product (PPP GDP), which is calculated using the output-based approach to control for the development of countries. The PPP GDP data are measured in millions of 2011 U.S. dollars.

\footnotetext{
${ }^{3}$ Time fixed effects utilized in our regression approach should account for variation in $\mathrm{CO}_{2}$ measurements that are unaccounted for in the data collection process.
} 
We also employ the PWT's human capital index $(\mathrm{HCl})$. The $\mathrm{HCl}$ is indicative of technological development as it is based on years of schooling, returns to education, and health outcomes. It "quantifies the contribution of health and education to the productivity of the next generation of workers" [40] and is thus a good proxy for the continued economic development of countries. A combination of health and educational variables contribute to economic development: better health outcomes, such as greater adult survival rates, imply a larger working population; better schooling is associated with higher productivity of labour and better decision making with respect to farm management practices [19, 25]. Put simply, "controlling for other [variables], more educated countries do tend to be more productive than others" [5], where productivity applies to the efficacy of farmers and their crops. Health outcomes at the micro level are positively correlated with agricultural productivity, although the causal relationship between the two is confounded by simultaneity since improved health outcomes lead to greater agricultural productivity and higher agricultural productivity leads to better health outcomes [22]. In our analysis, we do not look explicitly at the effects of human capital on agricultural productivity, but rather we control for differences in yields attributable to human capital to isolate marginal climate impacts. Human capital, more generally, is crucial for modernizing agriculture in developing countries [15]. In essence, the $\mathrm{HCl}$ represents a combination of variables that likely influence crop yields through its indirect measurement of economic development. We must control for these differences above and beyond simply the differences in real income, because human capital is an input in agricultural production.

In relation to our analysis, real GDP and $\mathrm{HCl}$ control for variation in yields attributable to economic growth. Countries that are more established and developed have greater investment in agribusiness, research and development (R\&D), and irrigation technologies (see Chapter 11 in Schmitz et al. [33] for a discussion on agricultural R\&D). Developed countries have greater agricultural productivity from access to newer technology, improved management practices, and organization [2], which leads to greater returns from resources and, similarly, greater crop yields over their less developed counterparts. Further, Ashton [2, p.15] states that the size of agricultural markets in developing countries are largely constrained by things such as price supports and competition for resources [2]. Further, in developing countries where returns to capital in agriculture are low relative to other industries, the availability of capital is lessened. This becomes problematic as there are large substitutions of labour for capital that contribute to the efficacy of the agricultural sector as countries develop and improve their practices. As such, countries with more human and physical capital see greater returns from employment in the agricultural sector. Inclusion of these factors further allows us to isolate the parameters of interest.

\subsection{Modifications to the data}

From 1961 to 2013, political changes in countries such as Sudan, the Soviet Union and Ethiopia have likely had negative effects on crop yields. Several modifications were made to the data to capture these and other extraneous factors that might have impacted yields:

a. The USSR disintegrated into fifteen separate states in 1991. We employ data for the USSR for the period 1961-1991, and data for the Russian Federation for 1992-2017, both under the rubric of Russia.

b. Ethiopia data consist of information for the Ethiopian PDR for 1961-1992, and Ethiopia for 1993-2017.Ethiopia data consist of information for the Ethiopian PDR for 1961-1992, and Ethiopia for 1993-2017.

c. China is treated as a single entity referring to the mainland only, and ignoring data for Taiwan.

d. South Sudan is ignored completely.

e. Serbia and Montenegro are removed as a combined country and treated as separate entities.Serbia and Montenegro are removed as a combined country and treated as separate entities.

f. Yugoslav SFR is ignored as it no longer exists.

There are some challenges that could reduce the accuracy of our results. First, the production map provided by the USDA is a rough approximation of crop production and national average temperatures for most countries. Based on geographic area, we determine which countries' regional data to use and which national average data are based on whether the country exhibits a lot of variation in temperatures. Second, we use annual temperature data that do not adequately consider the actual growing seasons for various crops. For example, in some countries two or more crops can be grown annually on the same parcel of land, but not in other countries.

Third, there are different varieties (cultivars) of the same crop. Crops such as wheat and rapeseed may be planted in fall (referred to as winter wheat/rapeseed) or spring; fall plantings spread machine operations to save costs and provide an impetus to plant growth in early spring, but run the risk that the crop is killed over winter. Different cultivars and planting times can lead to dissimilar responses to climate. Given lack of data, we are unable to account for these factors.

Finally, as indicated above, the assumption that levels of $\mathrm{CO}_{2}$ are uniformly distributed across all global regions is rather strong. The $\mathrm{CO}_{2}$ data are provided by NOAA's Carbon 
Cycle Group and uses measures of monthly mean $\mathrm{CO}_{2}$ measured at the Mauna Loa Observatory in Hawaii. Our results depend on how quickly and evenly $\mathrm{CO}_{2}$ spreads throughout the atmosphere.

\subsection{Fixed effects panel regression model}

For each crop, we employ the following regression model: the analysis because such data are not available at this scale. Since variations in solar radiation are related to temperature responses through photorespiration [16], there is a potential endogeneity issue if solar radiation were included as an explanatory variable. Since we include both linear and quadratic terms, the fixed-effects model utilizes both within- and across-country differences in weather [18]. This approach overcomes omitted variable bias associated with fixed

$Y_{i t}=\beta_{0}+\beta_{1} \mathrm{CO}_{2}+\beta_{2} T_{i t}+\beta_{3} \mathrm{CO}_{2}^{2}+\beta_{4} T_{i t}^{2}+\beta_{5} \mathrm{CO}_{2} \times T_{i t}+\sum_{k=1}^{K} \alpha_{k} X_{k, i t}+\gamma_{i t}+\zeta_{t}+u_{i t}$

where $Y_{i t}$ refers to the yield in country $i$ at time $t ; \mathrm{CO}_{2}$ refers to the average annual level of $\mathrm{CO}_{2}$ in the atmosphere; $T_{i t}$ is the annual temperature $\left({ }^{\circ} \mathrm{C}\right)$ in country $i$ in year $t ; X_{k, i t}$ refers to one of $K$ socio-demographic control variables; $\beta_{j}(j=1, \ldots, 5)$ and $\alpha_{k}(k=1, \ldots, K)$ are parameters to be estimated; $\gamma_{i t}$ and $\zeta_{t}$ are the time and country fixed effects, respectively; and $u_{i t}$ is the error term that accounts for any variation caused by omitted variables. Quadratic terms for temperature and $\mathrm{CO}_{2}$, as well as an interaction term, reflect inherent and expected nonlinearities, even though these are not statistically significant for all crops.

We utilize a fixed-effects regression model to exploit variation across time periods within countries and between countries. This allows us to examine how crop yields have changed. The essence of fixed effects is that they control for time-invariant regressors that are excluded from the model. In the current context, this would include whether a country has a tropical or temperate climate, and the soil quality within a region, because they do not vary much over time. This allows our independent regressors to be correlated with time-invariant components of the error term; that is, it allows for a specific type of endogeneity. It does not, however, control for time variant components of the error term. Conventional Generalized Least Squares (GLS) standard errors are employed in all regressions so as to ensure the F-statistics are not singular. A discussion regarding the robustness of results to the inclusion of heteroskedasticity cluster-robust standard errors is included in Sect. 4. Further, we utilize country-specific time fixed effects to allow underlying trends in yields to differ between countries. Rather than relying on a common underlying trend in yield growth, country-specific trends account for differences in how yield grows over time that is not attributable to other variables included in our model (such as temperature). This should control for countries with majority irrigated and non-irrigated crops as these are likely implemented at different points in time within different countries. Further, this should control for some of the variation in crop yields that are attributable to precipitation.

Determinants of crop yields such as photorespiration, nitrogen availability, and precipitation are excluded from characteristics.

\section{Results}

Our interest is to uncover marginal effects, which we do by comparing our full model specification with two sets of controls to alternatives that have fewer control variables. To estimate the regression equations, we developed statistical programs written in R [27], version 1.1.463) and Stata [34]. The regression results for each of the various crops are provided in Tables 3, 4 and 5. ${ }^{4}$

\subsection{Level effects}

Consider the results for wheat in Table 3. In each of the regressions reported in the table, the signs on the coefficients on $\mathrm{CO}_{2}$ are positive and statistically significant and those of the quadratic terms are both negative and statistically significant. The coefficients on the linear and quadratic temperature terms are both negative and statistically significant, except for in the last specification where the linear term is statistically insignificant. The interaction term is positive in all specifications except in the last specification where human capital has been added as a variable - this suggests that the model suffered from omitted variable bias prior to the addition of controls. The positive interaction term implies that the $\mathrm{CO}_{2}$-fertilization effect is more effective at higher temperatures. The marginal effects of $\mathrm{CO}_{2}$ on wheat yields exhibits diminishing returns, with the effect of $\mathrm{CO}_{2}$ on yields further increasing at higher temperatures. The effect of adding more controls in the regression is to increase the overall fit of the model (as indicated by the increase in adjusted $R^{2}$, denoted $R^{2}$ ). It also suggests that the effects of $\mathrm{CO}_{2}$ and temperature are overstated in

\footnotetext{
${ }^{4}$ We also ran a version of the regression model that included all of the crop yield data, with dummy variables for crop types. The results turned out to be similar but statistically weaker.
} 
Table 3 Wheat and Maize Regression Analysis ${ }^{\mathbf{a}}$

\begin{tabular}{|c|c|c|c|c|c|c|}
\hline \multirow[t]{2}{*}{ Variables } & \multicolumn{3}{|l|}{ Wheat } & \multicolumn{3}{|l|}{ Maize } \\
\hline & (1) & $(2)$ & (3) & (4) & (5) & (6) \\
\hline $\mathrm{CO}_{2}$ & $\begin{array}{l}0.0915^{* * *} \\
(4.48)\end{array}$ & $\begin{array}{l}0.1030^{* * *} \\
(4.92)\end{array}$ & $\begin{array}{l}0.1010^{* * *} \\
(4.83)\end{array}$ & $\begin{array}{l}-0.0502^{* *} \\
(-2.26)\end{array}$ & $\begin{array}{l}-0.0642^{* * *} \\
(-2.81)\end{array}$ & $\begin{array}{l}-0.0660^{* * *} \\
(-2.89)\end{array}$ \\
\hline $\mathrm{CO}_{2}$-squared & $\begin{array}{l}-0.0001^{* * *} \\
(-5.49)\end{array}$ & $\begin{array}{l}-0.0001^{* * *} \\
(-5.95)\end{array}$ & $\begin{array}{l}-0.0001^{* * *} \\
(-5.69)\end{array}$ & $\begin{array}{l}0.0000 \\
(0.66)\end{array}$ & $\begin{array}{l}0.0000 \\
(1.38)\end{array}$ & $\begin{array}{l}0.0000 \\
(1.58)\end{array}$ \\
\hline Temperature & $\begin{array}{l}-0.1420^{* *} \\
(-2.08)\end{array}$ & $\begin{array}{l}-0.159^{* *} \\
(-2.33)\end{array}$ & $\begin{array}{l}-0.0708 \\
(-0.96)\end{array}$ & $\begin{array}{l}-0.7870^{* * *} \\
(-10.24)\end{array}$ & $\begin{array}{l}-0.767^{* * *} \\
(-9.94)\end{array}$ & $\begin{array}{l}-0.692^{* * *} \\
(-8.56)\end{array}$ \\
\hline Temp-squared & $\begin{array}{l}-0.0018^{* * *} \\
(-3.26)\end{array}$ & $\begin{array}{l}-0.0018^{* * *} \\
(-3.23)\end{array}$ & $\begin{array}{l}-0.0018^{* * *} \\
(-3.31)\end{array}$ & $\begin{array}{l}-0.0011^{*} \\
(-1.73)\end{array}$ & $\begin{array}{l}-0.0011^{*} \\
(-1.69)\end{array}$ & $\begin{array}{l}-0.0012^{*} \\
(-1.80)\end{array}$ \\
\hline $\mathrm{CO}_{2} \times \mathrm{Temp}$ & $\begin{array}{l}0.0004^{* *} \\
(2.29)\end{array}$ & $\begin{array}{l}0.0004^{* *} \\
(2.52)\end{array}$ & $\begin{array}{l}0.0002 \\
(1.13)\end{array}$ & $\begin{array}{l}0.0022^{* * *} \\
(10.24)\end{array}$ & $\begin{array}{l}0.0021^{* * *} \\
(9.92)\end{array}$ & $\begin{array}{l}0.0019^{* * *} \\
(8.53)\end{array}$ \\
\hline Constant & $\begin{array}{l}-22.91^{* *} \\
(-2.35)\end{array}$ & $\begin{array}{l}-18.47^{*} \\
(-1.87)\end{array}$ & $\begin{array}{l}-15.29 \\
(-1.54)\end{array}$ & $\begin{array}{l}-25.29^{* *} \\
(-2.38)\end{array}$ & $\begin{array}{l}-30.57^{* * *} \\
(-2.84)\end{array}$ & $\begin{array}{l}-27.86^{* * *} \\
(-2.58)\end{array}$ \\
\hline Observations & 2096 & 2096 & 2096 & 2307 & 2307 & 2307 \\
\hline Adjusted $\mathrm{R}^{2}$ & 0.727 & 0.728 & 0.729 & 0.785 & 0.785 & 0.787 \\
\hline F-statistic & $111.5^{* * *}$ & $109.7^{* * *}$ & $108.4^{* * *}$ & $151.9^{* * *}$ & $149.8^{* * *}$ & $147.9^{* * *}$ \\
\hline Countries & 46 & 46 & 46 & 51 & 51 & 51 \\
\hline GDP/capita & no & yes & yes & no & yes & yes \\
\hline Human capital & no & no & yes & no & no & yes \\
\hline
\end{tabular}

${ }^{a}$ t-statistics are reported in parentheses

Significance levels: ${ }^{* * *} p<0.01,{ }^{* *} p<0.05,{ }^{*} p<0.10$

Table 4 Soybean and Rapeseed Regression Analysis ${ }^{\mathbf{a}}$

\begin{tabular}{|c|c|c|c|c|c|c|}
\hline \multirow[t]{2}{*}{ Variables } & \multicolumn{3}{|l|}{ Soybean } & \multicolumn{3}{|l|}{ Rapeseed } \\
\hline & (1) & $(2)$ & (3) & (4) & (5) & (6) \\
\hline $\mathrm{CO}_{2}$ & $\begin{array}{l}0.0391 \\
(1.36)\end{array}$ & $\begin{array}{l}0.0312 \\
(1.06)\end{array}$ & $\begin{array}{l}0.0313 \\
(1.06)\end{array}$ & $\begin{array}{l}-0.0618^{*} \\
(-1.83)\end{array}$ & $\begin{array}{l}-0.0541 \\
(-1.57)\end{array}$ & $\begin{array}{l}-0.0713^{* *} \\
(-2.05)\end{array}$ \\
\hline $\mathrm{CO}_{2}$-squared & $\begin{array}{l}-0.0001^{* *} \\
(-2.08)\end{array}$ & $\begin{array}{l}-0.0001^{*} \\
(-1.68)\end{array}$ & $\begin{array}{l}-0.0001^{*} \\
(-1.68)\end{array}$ & $\begin{array}{l}0.0001^{*} \\
(1.68)\end{array}$ & $\begin{array}{l}0.0001 \\
(1.35)\end{array}$ & $\begin{array}{l}0.0001^{* *} \\
(2.00)\end{array}$ \\
\hline Temperature & $\begin{array}{l}-0.2140^{* *} \\
(-2.08)\end{array}$ & $\begin{array}{l}-0.210^{* *} \\
(2.336)\end{array}$ & $\begin{array}{l}-0.0212^{* *} \\
(-1.98)\end{array}$ & $\begin{array}{l}0.0127 \\
(0.11)\end{array}$ & $\begin{array}{l}-0.0000 \\
(-0.00)\end{array}$ & $\begin{array}{l}0.1520 \\
(1.24)\end{array}$ \\
\hline Temp-squared & $\begin{array}{l}-0.0003 \\
(-0.33)\end{array}$ & $\begin{array}{l}-0.0002 \\
(-0.30)\end{array}$ & $\begin{array}{l}-0.0002 \\
(-0.30)\end{array}$ & $\begin{array}{l}-0.0022^{* *} \\
(-2.23)\end{array}$ & $\begin{array}{l}-0.0021^{* *} \\
(-2.20)\end{array}$ & $\begin{array}{l}-0.0021^{* *} \\
(-2.14)\end{array}$ \\
\hline $\mathrm{CO}_{2} \times$ Temp & $\begin{array}{l}0.0005^{*} \\
(1.88)\end{array}$ & $\begin{array}{l}0.0005^{*} \\
(1.83)\end{array}$ & $\begin{array}{l}0.0005^{* *} \\
(1.78)\end{array}$ & $\begin{array}{l}0.0000 \\
(0.07)\end{array}$ & $\begin{array}{l}0.0001 \\
(0.17)\end{array}$ & $\begin{array}{l}-0.0004 \\
(-1.10)\end{array}$ \\
\hline Constant & $\begin{array}{l}-31.75^{* *} \\
(-2.28)\end{array}$ & $\begin{array}{l}-34.49^{* *} \\
(-2.44)\end{array}$ & $\begin{array}{l}-34.56^{* *} \\
(-2.43)\end{array}$ & $\begin{array}{l}-65.84^{* * *} \\
(-4.06)\end{array}$ & $\begin{array}{l}-62.48^{* * *} \\
(-3.78)\end{array}$ & $\begin{array}{l}-47.82^{* * *} \\
(-2.81)\end{array}$ \\
\hline Observations & 1,932 & 1,932 & 1,932 & 1,395 & 1,395 & 1,395 \\
\hline Adjusted $\mathrm{R}^{2}$ & 0.564 & 0.564 & 0.564 & 0.490 & 0.490 & 0.494 \\
\hline F-statistic & $51.82^{* * *}$ & $50.84^{* * *}$ & $49.83^{* * *}$ & $35.33^{* * *}$ & $34.50^{* * *}$ & $34.24^{* * *}$ \\
\hline Countries & 45 & 45 & 45 & 35 & 35 & 35 \\
\hline GDP/capita & no & yes & yes & no & yes & yes \\
\hline Human capital & no & no & yes & no & no & yes \\
\hline
\end{tabular}

${ }^{a}$ t-statistics are reported in parentheses

Significance levels: ${ }^{* * *} p<0.01,{ }^{* *} p<0.05,{ }^{*} p<0.10$ 
Table 5 Rice and Sorghum Regression Analysis ${ }^{\mathrm{a}}$

\begin{tabular}{|c|c|c|c|c|c|c|}
\hline \multirow[t]{2}{*}{ Variables } & \multicolumn{3}{|l|}{ Rice } & \multicolumn{3}{|l|}{ Sorghum } \\
\hline & (1) & $(2)$ & (3) & (4) & (5) & (6) \\
\hline $\mathrm{CO}_{2}$ & $\begin{array}{l}0.0576^{* * *} \\
(2.61)\end{array}$ & $\begin{array}{l}0.0839^{* * *} \\
(3.73)\end{array}$ & $\begin{array}{l}0.0837^{* * *} \\
(3.72)\end{array}$ & $\begin{array}{l}-0.0942^{* * *} \\
(-2.97)\end{array}$ & $\begin{array}{l}-0.103^{* * *} \\
(-3.19)\end{array}$ & $\begin{array}{l}-0.103^{* * *} \\
(-3.17)\end{array}$ \\
\hline $\mathrm{CO}_{2}$-squared & $\begin{array}{l}-0.0000^{* *} \\
(-2.01)\end{array}$ & $\begin{array}{l}-0.0001^{* * *} \\
(-3.40)\end{array}$ & $\begin{array}{l}-0.0001^{* * *} \\
(-3.37)\end{array}$ & $\begin{array}{l}0.0000 \\
(0.82)\end{array}$ & $\begin{array}{l}0.0000 \\
(1.16)\end{array}$ & $\begin{array}{l}-0.0000 \\
(1.11)\end{array}$ \\
\hline Temperature & $\begin{array}{l}0.2670^{* * *} \\
(2.94)\end{array}$ & $\begin{array}{l}0.2300^{* *} \\
(2.53)\end{array}$ & $\begin{array}{l}0.2370^{* *} \\
(2.55)\end{array}$ & $\begin{array}{l}-1.1640^{* * *} \\
(-9.53)\end{array}$ & $\begin{array}{l}-1.1370^{* * *} \\
(-9.18)\end{array}$ & $\begin{array}{l}-1.1750^{* * *} \\
(-9.09)\end{array}$ \\
\hline Temp-squared & $\begin{array}{l}-0.0025^{* * *} \\
(-2.90)\end{array}$ & $\begin{array}{l}-0.0027^{* * *} \\
(-3.14)\end{array}$ & $\begin{array}{l}-0.0027^{* * *} \\
(-3.15)\end{array}$ & $\begin{array}{l}-0.0007 \\
(-0.63)\end{array}$ & $\begin{array}{l}-0.0006 \\
(-0.58)\end{array}$ & $\begin{array}{l}-0.0006 \\
(-0.54)\end{array}$ \\
\hline $\mathrm{CO}_{2} \times$ Temp & $\begin{array}{l}-0.0005^{* *} \\
(-2.04)\end{array}$ & $\begin{array}{l}-0.0004 \\
(-1.54)\end{array}$ & $\begin{array}{l}-0.0004 \\
(-1.59)\end{array}$ & $\begin{array}{l}0.0033^{* * *} \\
(9.95)\end{array}$ & $\begin{array}{l}0.0032^{* * *} \\
(9.54)\end{array}$ & $\begin{array}{l}0.0033^{* * *} \\
(9.43)\end{array}$ \\
\hline Constant & $\begin{array}{l}-8.667 \\
(-0.82)\end{array}$ & $\begin{array}{l}1.047 \\
(0.10)\end{array}$ & $\begin{array}{l}1.239 \\
(0.12)\end{array}$ & $\begin{array}{l}-16.71 \\
(-1.12)\end{array}$ & $\begin{array}{l}-20.29 \\
(-1.33)\end{array}$ & $\begin{array}{l}-21.51 \\
(-1.41)\end{array}$ \\
\hline Observations & 2,013 & 2,013 & 2,013 & 1,720 & 1,720 & 1,720 \\
\hline Adjusted $\mathrm{R}^{2}$ & 0.633 & 0.638 & 0.638 & 0.480 & 0.481 & 0.481 \\
\hline F-statistic & $77.35^{* * *}$ & $77.31^{* * *}$ & $75.66^{* * *}$ & $37.99^{* * *}$ & $37.20^{* * * *}$ & $36.42^{* * *}$ \\
\hline Countries & 41 & 41 & 41 & 39 & 39 & 39 \\
\hline GDP/capita & no & yes & yes & no & yes & yes \\
\hline Human capital & no & no & yes & no & no & yes \\
\hline
\end{tabular}

${ }^{\mathrm{a}} \mathrm{t}$-statistics are reported in parentheses

Significance levels: ${ }^{* *} p<0.01,{ }^{* *} p<0.05,{ }^{*} p<0.10$ the original regression and we control for this bias with the addition of GDP per capita and the human capital index. The F-statistic for the test of joint significance of the regressors is large indicating that the regressors are jointly significant, and this result holds for the specifications for every crop.

If we consider maize, we find that the quadratic term for $\mathrm{CO}_{2}$ is very close to zero and insignificant. It seems that the impact of $\mathrm{CO}_{2}$ on maize yields is weak, although yields decrease with higher temperatures. Overall, however, we are unable to uncover the full extent of these effects for maize, likely due to our limited $\mathrm{CO}_{2}$ data. This is discussed further when we examine the marginal effects of $\mathrm{CO}_{2}$ and temperature on yields. In this case, the addition of more controls, as indicated in column (4) of Table 3, increases $\overrightarrow{R^{2}}$ only slightly.

Now consider the results in Table 4. The signs on the linear term for $\mathrm{CO}_{2}$ are positive for soybean although statistically insignificant. The linear term for temperature is negative and statistically significant at the $5 \%$ level of significance. The quadratic terms are negative, indicating diminishing benefits and, eventually, a decline in yields. The interaction between $\mathrm{CO}_{2}$ and temperature is positive as in the wheat regressions, indicating that $\mathrm{CO}_{2}$-fertilization is more effective at higher temperatures. The addition of controls does not change the results very much, although the estimated parameter on the linear $\mathrm{CO}_{2}$ term falls slightly in the case of soybean, indicating that omitted variable bias could be present. The estimated effect of the interaction between $\mathrm{CO}_{2}$ and temperature is statistically significant. In the case of rapeseed, yields are negatively correlated with increases in temperature and $\mathrm{CO}_{2}$. The quadratic term for $\mathrm{CO}_{2}$ is not statistically different from zero. Overall, the statistical fits of the regression models $\left(\mathrm{R}^{2}\right)$ for soybean and rapeseed are smaller than in the case of wheat and maize, further implying that there may be excluded variables that affect soybean and rapeseed yields. The negative impacts from $\mathrm{CO}_{2}$-fertilization for rapeseed are not robust to the inclusion of cluster-robust standard errors. The impact is not statistically different from zero in this case.

Finally consider the regression results for rice and sorghum in Table $5 . \mathrm{CO}_{2}$ and temperature have a statistically significant positive impact on rice yields, although both exhibit diminishing returns. Adding GDP per capita as a control variable in specification (2) leads to a large increase in the linear $\mathrm{CO}_{2}$ term, which implies that the original specification suffered from omitted variable bias that biased the result downwards. Likewise, the linear temperature term is biased in the original specification, with the estimated coefficient falling upon the addition of the controls. The interaction between $\mathrm{CO}_{2}$ and temperature is negative and statistically significant at the $5 \%$ level in the first specification, but slightly lower and just shy of statistical significance at the $10 \%$ level in the remaining specifications.

As for sorghum, all coefficients reflect their expected signs and are similar to those found for other crops (except rice). The only statistically insignificant estimates are those 
on the quadratic terms for temperature and $\mathrm{CO}_{2}$; however, its magnitude is not dissimilar to previous regressions. All interaction effects in the sorghum regression are negative and statistically insignificant. Likewise, the effect of an increase in temperature also diminishes at higher levels of atmospheric $\mathrm{CO}_{2}$. All terms, except the interaction term, are negative for sorghum, which is not what was expected. The interaction term between $\mathrm{CO}_{2}$ and temperature is positive, statistically significant at the $1 \%$ level of significance, and unchanged with the addition of control variables. The damage from rising $\mathrm{CO}_{2}$ is not robust to the inclusion cluster-robust standard errors as the linear term is no longer statistically significant under this alternative specification. This implies that the results for sorghum should be taken with a grain of salt.

\subsection{Marginal effects}

The equations of the marginal effects for each of the fullyspecified models (3) and (6) in Tables 3 through 5 are provided in Table 6 . These are then evaluated at the average levels of $\mathrm{CO}_{2}$ and temperature so that we can isolate the main effects of these two climate variables on each type of crop. We then compute tipping points by setting the first-order partial derivatives with respect to both $\mathrm{CO}_{2}$ and temperature equal to zero and solving for $\mathrm{CO}_{2}$ and temperature, respectively. This gives us the tipping points at which an increase in temperature or $\mathrm{CO}_{2}$ leads to falling crop yields.

Starting at an atmospheric $\mathrm{CO}_{2}$ concentration of $400 \mathrm{ppm}$, a $100 \mathrm{ppm}$ increase at current average temperatures for each crop growing region leads to a slight decrease in expected wheat and rapeseed yields of $0.780 \%$ and $0.778 \%$, respectively, while rice yields are expected to increase by $1.45 \%$. These changes in yields are worse for wheat and rapeseed at above-average temperatures, and higher for rice yields at higher temperatures. This latter result is good news for developing countries located in semi-arid regions. Starting at a temperature of $20^{\circ} \mathrm{C}$, a $1{ }^{\circ} \mathrm{C}\left(2{ }^{\circ} \mathrm{C}\right)$ increase is expected to result in a dramatic fall in maize yields by $73.8 \%$ (147.6\%), while rice yields are expected to rise by $12.98 \%$ ( $25.96 \%)$. The estimated dramatic reduction in maize yields is entirely unrealistic and does not fit within the scope of the literature. However, the result for rice is good news as rice is typically grown in hotter climates, although the benefits from rising temperatures diminish quickly. For similar increase(s) in temperature beginning with $30^{\circ} \mathrm{C}$, rice yields are expected to increase by $7.62 \%$ (15.24\%).

For comparison, Schlenker and Roberts [32] (p. 37) found that a $1{ }^{\circ} \mathrm{C}\left(2{ }^{\circ} \mathrm{C}\right)$ increase in temperature, corn (maize) yields decreased by $6.38 \%(14.87 \%)$ and soybean yields fell by $3.17 \%$ (8.89\%). Zhao et al. [41] found that a $1{ }^{\circ} \mathrm{C}\left(2{ }^{\circ} \mathrm{C}\right)$ increase in temperature (ignoring a $\mathrm{CO}_{2}$-fertilization effect) is associated with reductions of wheat yields by $6.0 \%(12.0 \%)$, rice yields by $3.2 \%(6.4 \%)$, maize by $7.4 \%(14.8 \%)$, and soybean yields by $3.1 \%$ $(6.2 \%)$. Their results for rice are opposite our results, and considerably lower; they find rising temperatures to be damaging to rice yields whereas we find them to be beneficial. They also find stark reductions in maize production in the U.S., among other countries, of $10.3 \pm 5.4 \%$ per ${ }^{\circ} \mathrm{C}$. Their approach differs from ours in that they are using modeled temperature scenarios, whereas we use observational data.

We can compute tipping points as estimates of parameter values using their averages computed from the regression models. For example, the tipping point for $\mathrm{CO}_{2}$ takes the following functional form:

Table 6 Marginal Effects for $\mathrm{CO}_{2}$ and Temperature by Crop

\begin{tabular}{lll}
\hline Crop & $\partial$ Yield $/ \partial \mathrm{CO}_{2}$ & $\partial$ Yield $/ \partial \mathrm{T}$ \\
\hline Wheat & $0.101-0.000272 \times \mathrm{CO}_{2}-\underline{0.000232} \times(T-\bar{T})$ & $-\underline{0.0708}-0.00362 \times T-\underline{0.000232} \times\left(\mathrm{CO}_{2}-\overline{\mathrm{CO}}_{2}\right)$ \\
Maize & $-0.066+\underline{0.0000824} \times \mathrm{CO}_{2}-0.00191 \times(T-\bar{T})$ & $-0.692-0.0023 \times T-0.00191 \times\left(\mathrm{CO}_{2}-\overline{\mathrm{CO}}_{2}\right)$ \\
ybean & $\underline{0.0313}-0.0001134 \times \mathrm{CO}_{2}-0.000527 \times(T-\bar{T})$ & $-0.212-\underline{0.000494} \times T-0.000527 \times\left(\mathrm{CO}_{2}-\overline{\mathrm{CO}}_{2}\right)$ \\
Rapeseed & $-0.0713+0.0001588 \times \mathrm{CO}_{2}-\underline{0.000407} \times(T-\bar{T})$ & $0.152-0.00414 \times T-\underline{0.000407 \times\left(\mathrm{CO}_{2}-\overline{\mathrm{CO}}_{2}\right)}$ \\
Rice & $0.0837-0.000173 \times \mathrm{CO}_{2}+\underline{0.000407} \times(T-\bar{T})$ & $0.237-0.00536 \times T-\underline{0.000407} \times\left(\mathrm{CO}_{2}-\overline{\mathrm{CO}_{2}}\right)$ \\
Sorghum & $-0.103+\underline{0.0000818} \times \mathrm{CO}_{2}-0.00331 \times(T-\bar{T})$ & $-1.175-\underline{0.001138 \times T-0.00331 \times\left(\mathrm{CO}_{2}-\overline{\mathrm{CO}}_{2}\right)}$
\end{tabular}

${ }^{a}$ Marginal effects are derived from the final specifications of regression models in columns (3) and (6) in each of Tables 3,4 and 5. Parameters that are underlined indicate that these are statistically insignificant at the $10 \%$ level or better. The marginal effect of $\mathrm{CO}_{2}$ (temperature) can be evaluated at the average level of temperature $\left(\mathrm{CO}_{2}\right)$ so as to isolate the main effects 
Table 7 Crop Yield Tipping Points, $\mathrm{CO}_{2}$ and Temperature ${ }^{\mathrm{a}}$

\begin{tabular}{lll}
\hline Crop & $\mathrm{CO}_{2}(\mathrm{ppm})^{\mathrm{a}}$ & Temperature $\left({ }^{\circ} \mathrm{C}\right)$ \\
\hline Wheat & 371.32 & $\mathrm{NA}$ \\
Maize & 800.97 & $\mathrm{NA}$ \\
Soybean & $\mathrm{NA}$ & $\mathrm{NA}$ \\
Rapeseed & 448.99 & $\mathrm{NA}$ \\
Rice & 483.82 & 44.22 \\
Sorghum & $\mathrm{NA}$ & $\mathrm{NA}$ \\
\hline
\end{tabular}

${ }^{\mathrm{a}} \mathrm{NA}$ reflects the fact that yields are not sensitive to changes in $\mathrm{CO}_{2}$ or temperature

$\mathrm{CO}_{2}=-[a+c \times(T-\bar{T})] / b$,

where $a$ and $b$ are the linear and quadratic terms associated with $\mathrm{CO}_{2}$, and $\mathrm{c}$ is the coefficient for the interaction term between $\mathrm{CO}_{2}$ and temperature. We use sample data for the demeaned temperature term, and the same for the $\mathrm{CO}_{2}$ in the analogous tipping point for temperature:

$T=-\left[d+f \times\left(\overline{\mathrm{CO}_{2}}\right)\right] / e$,

where, similarly, $d$ and $e$ are the linear and quadratic terms associated with temperature, and $f(=c)$ is the coefficient for the interaction term between $\mathrm{CO}_{2}$ and temperature. Most of the marginal effects of temperature on crop yields do not have the a priori expected signs for each crop, which generates problems in identifying tipping points-marginal effects with negative coefficients on both the linear and quadratic terms of $\mathrm{CO}_{2}$ and/or temperature generate negative tipping points. Negative tipping points for temperature are inherently incorrect as they do not properly characterize the positive benefits of rising temperature that have been found in the literature. Where temperature is damaging is at points where it is too hot or too cold to grow crops. The results for estimated tipping points at average values of $\mathrm{CO}_{2}$ and temperature are reported in Table 7.

The lack of statistical significance in our tipping points for temperature is indicative of the fact that we are not properly identifying this relationship by using surface air temperatures. As for wheat, we are measuring a combination of winter and spring wheat; although they are typically the same cultivar, there are clear differences in the temperatures at which each crop is grown. The tipping point for wheat is the only one calculated using statistically significant parameters. The $\mathrm{CO}_{2}$ tipping points for wheat, maize, rapeseed, and rice are the only ones that are logically consistent. These tipping points indicate that we have already gathered much of the benefits from $\mathrm{CO}_{2}$-fertilization for wheat; maize will see positive impacts for decades to come; rapeseed and rice are both still experiencing increasing yields from rising $\mathrm{CO}_{2}$, but these are rapidly diminishing. As for temperature, most of the tipping points do not make sense and, as pointed out above, indicate we may not be obtaining proper estimates of the temperature impacts. The only two tipping points of interest are those for rapeseed and rice. Rapeseed will start seeing temperature damages beyond average temperatures of $36^{\circ} \mathrm{C}$, although the marginal effects associated with this tipping point are statistically insignificant; and rice will see damages occurring beyond $44^{\circ} \mathrm{C}$, well above current average temperatures in most developing countries.

Figures 3 and 4 show plots of the marginal effects (and hence tipping points) associated with statistically significant marginal effects at varying levels of $\mathrm{CO}_{2}$ and temperature. Though these tipping points should be taken with a grain of salt due to the lack of significance. The only statistically significant marginal temperature effect is rice. The statistically significant $\mathrm{CO}_{2}$-fertilization effects are associated with wheat, maize, rapeseed, and rice.

Some of these marginal effects are inconsistent with the nature of the $\mathrm{CO}_{2}$-fertilization effect and lead us to recommend that there should be further research in this area, taking a similar approach as we have done here, as more data become available. We are not entirely sure why the signs of the marginal temperature effects for most of these crops are incorrect, but it is likely a result of the lack of confounding variables in our data, as well as lack of regional $\mathrm{CO}_{2}$ data. With respect to the other marginal effects, we get $\mathrm{CO}_{2}$ tipping points that exhibit statistical significance for wheat, maize, rapeseed and rice at $371.32 \mathrm{ppm}, 800.97 \mathrm{ppm}, 448.99 \mathrm{ppm}$, and $483.82 \mathrm{ppm}$, respectively, although these results need to

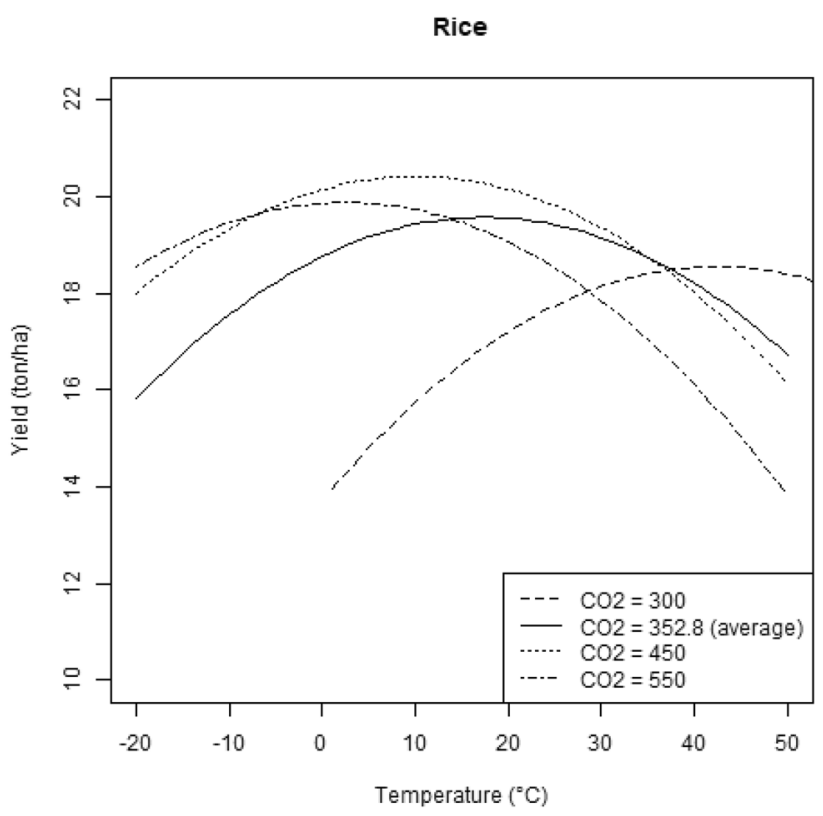

Fig. 3 Temperature Effects on Crop Yields at differing levels of $\mathrm{CO}_{2}$. Created using R Version 1.1.463 

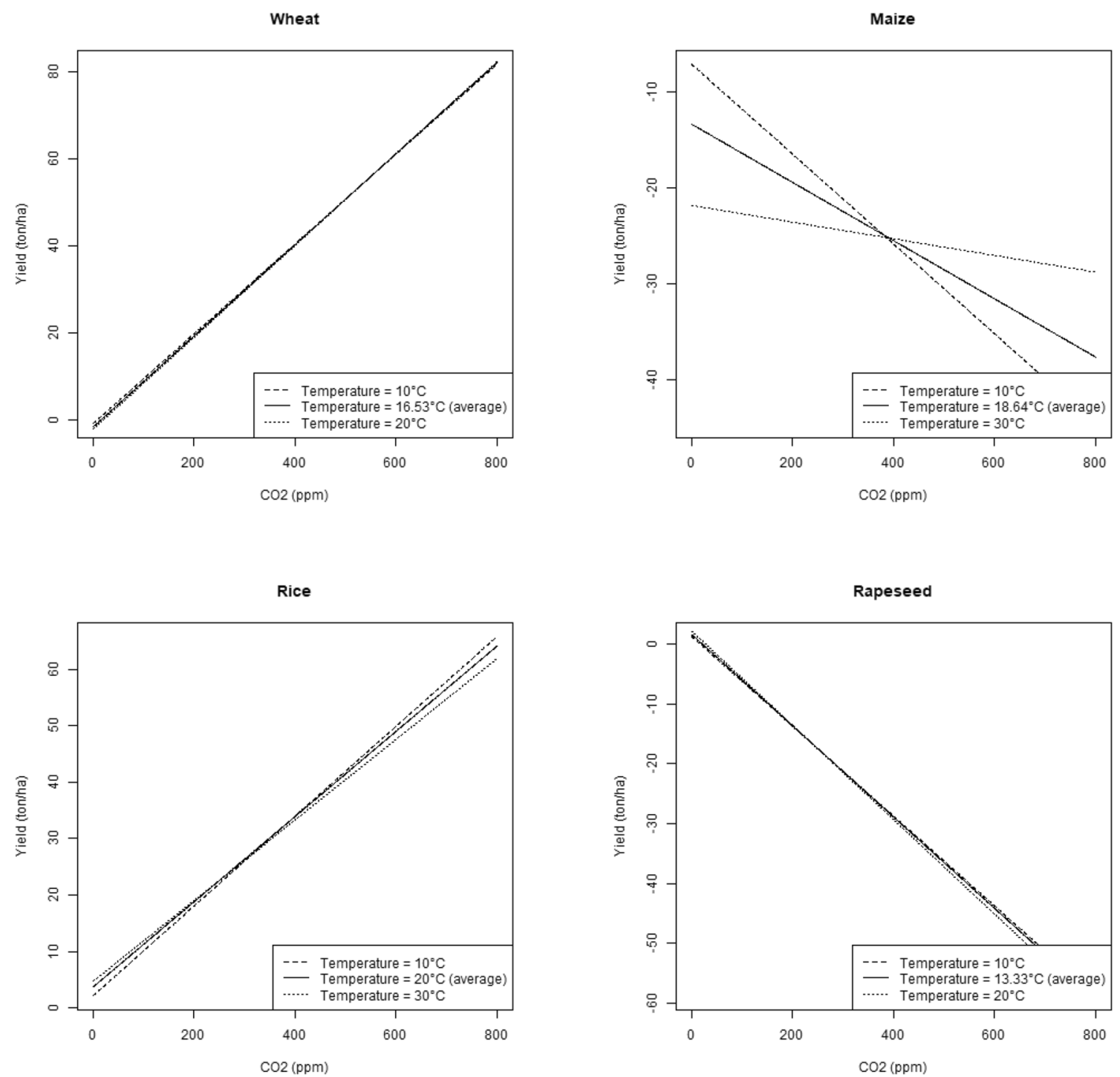

Fig. $4 \mathrm{CO}_{2}$-Fertilization Effects on Crop Yields at Different Temperatures. Created using R Version 1.1.463

be investigated further. A tipping point of $371.32 \mathrm{ppm}$ implies that we should now be witnessing damagesthese are inconsistent with the reality that crop yields have continually risen with increased $\mathrm{CO} 2$ in the atmosphere. However, given crop science research that points towards sustained but diminishing positive $\mathrm{CO}_{2}$ effects, it is important to consider why this is the case. As seen in Fig. 4, wheat and rice exhibit positive $\mathrm{CO}_{2}$-fertilization effects. Maize and rapeseed appear to be damaged by rising $\mathrm{CO}_{2}$, where maize is the only crop that appears to have a $\mathrm{CO}_{2}$-fertilization effect that is sensitive to changing temperatures-inconsistent with what the crop experiment literature has uncovered.

Further research using regional $\mathrm{CO}_{2}$ data is an obvious next step, because, at face value, the above tipping points imply that $\mathrm{CO}_{2}$ is already having negative effects on maize and rapeseed, which is not borne out by field trials and on-farm yields in many regions [21]. This would not explain why industrial farming techniques include consistently pumping $\mathrm{CO}_{2}$ into greenhouses to amplify the yields of these crops, leading us to believe that global $\mathrm{CO}_{2}$ is simply not a good enough proxy for identifying crop-specific regional effects on crop yields.

What can be gathered from the present analysis is the fact that the $\mathrm{CO}_{2}$-fertilization effect is prominent in some crops, but that it is not properly accounted for in other cases. The evidence also suggests that negative impacts of global warming on food security may be overstated as a result of overlooking $\mathrm{CO}_{2}$ as a determinant of crop yields. In the same sense that farmers pump $\mathrm{CO}_{2}$ into greenhouses to create an artificial environment, the globe will likely start to resemble these optimal environments as time progresses. 


\section{Conclusions}

Does climate change lead to greater food insecurity? This is a difficult question to answer. Food security might be compromised at the regional level, but not at the global level, or it might be compromised at both scales. Increasing concentrations of atmospheric $\mathrm{CO}_{2}$ can improve agricultural productivity, enabling crops to better utilize nutrients, including water. Higher levels of $\mathrm{CO}_{2}$ also make crops less susceptible to drought. While droughts might increase in some regions of the globe, overall a warmer atmosphere holds more moisture leading to increased rainfall. Nonetheless, there remains a fear that, as temperatures continue to rise with increasing $\mathrm{CO}_{2}$, the $\mathrm{CO}_{2}$-fertilization effect will be offset by too much heat. Indeed, using experimental data, Challinor et al. [4] found temperature was the dominant explanatory factor explaining both positive and negative changes in crop yields, with precipitation and $\mathrm{CO}_{2}$ fertilization playing a minor albeit yield-enhancing role. Our results based on historical, country-level crop yield data provide similar evidence regarding $\mathrm{CO}_{2}$ and temperatures. However, we are unable to identify potential tipping points where further increases in atmospheric $\mathrm{CO}_{2}$ and/or temperatures cause crop yields to decline.

The empirical evidence indicates that crop yields ( $\mathrm{t} / \mathrm{ha}$ ) have increased steadily since the $1960 \mathrm{~s}$. Average global yields of maize have increased by $2.0 \%$ annually over the period $1961-2016$, rice by $1.7 \%$, wheat by $2.1 \%$, sorghum by $0.9 \%$ and soybeans by $1.6 \%$. Yet, the majority of scientists believe that at higher temperatures, the adverse effect of heat on crop yields will eventually offset the benefits of $\mathrm{CO}_{2}$ fertilization. As we noted earlier, the U.S. National Climate Assessment report [39] projects that, while it expects U.S. crop yields to continue trending upwards, productivity growth will be lower than what it would be in the absence of climate change. One can only conclude that the evidence regarding the impact of climate change on agriculture is a matter of interpretation, dependent on which studies are chosen to support one's viewpoint and how the evidence is presented.

Future technological change remains the greatest unknown factor. New weather-indexed insurance products are increasingly becoming available, which will incentivize farmers to adapt to climate change by taking risks pertaining to new crops and cropping methods [14]. Global positioning satellites (GPS) can be used to guide equipment movement, while drones can be used to identify fungal and other pest invasions during the growing season, thereby enabling swift and effective targeting of chemical and fertilizer applications and optimal timing of harvests. New irrigation technologies that rely on swift and timely computer analyses, and water harvesting from early-morning fog (which occurs in some arid regions), are further examples of climate smart farming. These and other farm management technologies improve agricultural financial and environmental outcomes.

The greatest potential of future technological changes will likely come from biology. Plant breeding and genetic engineering will lead to different crops and crop varieties that produce higher yields and are more resilient to weather extremes, such as droughts, and offer protection against pests, fungus, and disease. Likewise, research can be expected to provide chemicals or biological agents that target weeds and insect pests, while being more benign in their environmental impact. Higher yield crops currently grown in temperate latitudes are increasingly adapted to tropical conditions where hours of sunlight are shorter but temperatures higher.

While it is difficult to predict what the future might hold in store for agriculture, one can be optimistic that technological changes will greatly improve the ability of agricultural producers to adapt to climate change. Only when the scope for technological improvements is ignored might global warming lead to famines and starvation in the future.

Acknowledgements We acknowledge the support of the Natural Sciences and Engineering Research Council of Canada (NSERC) ${ }^{\circ}$ Brennan McLachlan, G. Cornelis van Kooten and Zehan Zheng, 2020. All rights reserved. This extended essay may not be reproduced in whole or in part, by photocopy or other means, without the permission of the authors.

\section{References}

1. Adams DM, Alig RJ, Callaway JM, McCarl BA, Winnett SM (1996) The forest and agricultural sector optimization model (FASOM): model structure and policy applications. U.S. Department of Agriculture, Pacific Northwest Research Station, Portland, p 60

2. Ashton J (1973) Agriculture in developed countries: Competition for resources. Philos Trans R Soc B Biol Sci 267:13-21. Retrieved from https://www.jstor.org/stable/2417270

3. Berkeley Earth (2019) Berkeley earth surface temperature (BEST). Retrieved from https://berkeleyearth.lbl.gov/city-list/

4. Challinor AJ, Watson J, Lobell DB, Howden SM, Smith DR, Chhetri $\mathrm{N}$ (2014) A meta-analysis of crop yield under climate change and adaptation. Nat Clim 4:287-291

5. de la Fuente A, Doménech R (2000) Human capital in growth regressions: How much difference does data quality make? J Eur Econ Assoc 4(1):1-36. Retrieved from https://onlinelibrary. wiley.com/doi/10.1162/jeea.2006.4.1.1

6. Earth System Research Laboratory (2019) Trends in Atmospheric Carbon Dioxide. Mauna Loa, Hawaii. At https://www.esrl.noaa. gov/gmd/ccgg/trends/ [accessed November 18, 2019].

7. Feenstra RC, Inklaar R, Timmer MP (2015) The next generation of the Penn World Table. Am Econ Rev 105(10):3150-3182

8. Fischer RA (2008) The importance of grain or kernel number in wheat: a reply to Sinclair and Jamieson. Field Crops Res 105(1-2):15-21 
9. Food and Agriculture Organization of the United Nations (2019) FAOSTAT Database. Rome, Italy. Retrieved from https://www.fao. org/faostat/en/\#data

10. Gnanamanickam SS (2009) Biological control of rice diseases. Springer, Dordrecht

11. Hungria M, Franchini JC, Campo RJ, Graham PH (2005) The importance of nitrogen fixation to soybean cropping in South America. Ch. 3. In: Werner D, Newton WE (eds) Nitrogen fixation in agriculture, forestry, ecology, and the environment. Springer, Dordrecht

12. IPCC (2013) Climate Change 2013: The Physical Science Basis. Contribution of Working Group I to the Fifth Assessment Report of the Intergovernmental Panel on Climate Change [Stocker TF, Qin D, Plattner G-K, Tignor M, Allen SK, Boschung J, Nauels A, Xia Y, Bex V, Midgley PM (eds.)]. Cambridge University Press, Cambridge, United Kingdom and New York, NY, USA, 1535 pp. At https://www.ipcc.ch/report/ar5/wg1/ [accessed November $14,2019]$

13. IPCC (2018) Global Warming of 1.5oC. An IPCC special report on the impacts of global warming of $1.5 \mathrm{C}$ above pre-industrial levels and related global greenhouse gas emission pathways, in the context of strengthening the global response to the threat of climate change, sustainable development, and efforts to eradicate poverty. Geneva, Switzerland: U.N. Intergovernmental Panel on Climate Change. At https://ipcc.ch/report/sr15/ [accessed November 14, 2019]

14. Kramer B, Ceballos F (2018) Enhancing adaptive capacity through climate-smart insurance: theory and evidence from India. Paper presented at the International Conference of Agricultural Economists, July 28-August 2, Vancouver, Canada

15. Lanzona LA Jr (2014) Human capital and agricultural productivity: The case of the Philippines. Prod Growth Philipp Agric 10:1-24

16. Lean J, Rind D (1998) Climate forcing by changing solar radiation. JCLI 11(12):3069-3094

17. Lobell DB, Field CB (2007) Global scale climate-crop yield relationships and the impacts of recent warming. ERL 2(1):014002

18. Lobell DB, Schlenker W, Costa-Roberts J (2011) Climate trends and global crop production since 1980. Science 333(6042):616-620

19. Lockheed ME, Lau LJ (1980) Farmer education and farm efficiency: A survey. Econ Dev Cult Change 29(1):37-76

20. McCarl BA, Thayer AW, Jones JPH (2016) The challenge of climate change adaptation for agriculture: an economically oriented review. J Agric Appl Econ 48(4):321-344

21. McLachlan BA, van Kooten $\mathrm{GC}$, Zheng $Z$ (2020) $\mathrm{CO}_{2}$ Fertilization versus Temperature: a meta-regression analysis of crop yields. Under review

22. McNamara PE, Ulimwengu JM, Leonard KL (2010) Do health investments improve agricultural productivity? International Food Policy Research Institute, Discussion Paper 01012. Retrieved from: https://www.researchgate.net/publication/46442044_ Do_health_investments_improve_agricultural_productivity

23. Meinschausen M, Smith SJ, Calvin K, Daniel JS, Kainuma MLT, Lamarque JF, Matsumoto K, Montzka SA, Raper SCB, Riahi K, Thomson A, Velders GJM, van Vuuren DPP (2011) The RCP greenhouse gas concentrations and their extensions from 1765 to 2300. Clim Change 109(1-2):213-241

24. Moore FC, Baldos U, Hertel T, Diaz D (2017) New science of climate change impacts on agriculture implies higher social cost of carbon. Nat Commun 8(1):1607

25. Oduro-Ofori E, Aboagye Anokye P, Aku AN, E. (2014) Effects of education on the agricultural productivity of farmers in the Offinso municipality. Int J Dev Res 6(9):1951-1960

26. Porter JR, Howden M, Smith P (2017) Considering Agriculture in IPCC assessments. Nat Clim Change 7:680-683
27. R Core Team (2019) R: A Language and Environment for Statistical Computing. R Foundation for Statistical Computing, Vienna, Austria. Version 1.1.463

28. Rahmstorf S, Cazenave A, Church JA, Hansen JE, Keeling RF, Parker DE, Somerville RCJ (2007) Recent climate observations compared to projections. Science 316(5825):709

29. Riahi K, van Vuuren DP, Kriegler E, Edmonds J, O'Neill BC, Fujimori S, Bauer N, Calvin K, Dellink R, Fricko O, Lutz W, Popp A, Cuaresma JC, Samir KC, Leimbach M, Jiang L, Kram T, Rao S, Emmerling J, Ebi K, Hasegawa T, Havlik P, Humpenöder F, Da Silva LA, Smith S, Stehfest E, Bosetti V, Eom J, Gernaat D, Masui T, Rogelj J, Strefler J, Drouet L, Krey V, Luderer G, Harmsen M, Takahashi K, Baumstark L, Doelman JC, Kainuma M, Klimont Z, Marangoni G, Lotze-Campen H, Obersteiner M, Tabeau A, Tavoni $M$ (2017) The shared socioeconomic pathways and their energy, land use, and greenhouse gas emissions implications: An overview. Global Environ Chang 42:153-168

30. Rouf Shah T, Prasad K, Kumar P, Yildiz F (2016) Maize-a potential source of human nutrition and health: a review. Cogent Food Agric 2(1):1166995

31. Ryan S (1995) Quiescent outgassing of Mauna Loa volcano 1958-1994. In Rhodes JM, Lockwood JP (eds) Mauna Loa Revealed: Structure, Composition, History, and Hazards, Vol. 92, Geophysical Monograph Series American Geophysical Union. https://doi.org/10.1029/GM092

32. Schlenker W, Roberts MJ (2009) Nonlinear temperature effects indicate severe damages to US crop yields under climate change. PNAS 106(37):15594-15598

33. Schmitz A, Moss C, Schmitz TG, van Kooten GC, Schmitz HC (2010) Forthcoming. Agricultural policy, agribusiness and rent seeking behaviour. 3red edition. University of Toronto Press, Toronto

34. StataCorp (2019) Stata Statistical Software: Release 15. StataCorp LLC, College Station, TX. Version 15.1

35. Stevenson JR, Villoria N, Byerlee D, Kelley T, Maredia M (2013) Green revolution research saved an estimated 18-27 million hectares from being brought into agricultural production. PNAS 110(21):8363-8368

36. Taylor JRN (2003) Overview: the importance of sorghum in Africa. Proceedings of AFRIPRO Workshop on the Proteins of Sorghum and Millets: Enhancing Nutritional and Functional Properties for Africa, Pretoria, South Africa

37. United Nations (2015). Adoption of Paris Agreement. Retrieved from: https://unfccc.int/resource/docs/2015/cop21/eng/l09r01.pdf

38. United States Department of Agriculture, Foreign Agricultural Service (2019) Crop Production Maps for Major Crop RegionsUnited States Department of Agriculture. Retrieved from https ://ipad.fas.usda.gov/ogamaps/cropproductionmaps.aspx

39. USGCRP (2018) Impacts, Risks, and Adaptation in the United States: Fourth National Climate Assessment, Volume II,edited by Reidmiller DR, Avery CW, Easterling DR, Kunkel KE, Lewis KLM, Maycock TK, Stewart BC, Washington, DC: U.S. Global Change Research Program. https://doi.org/10.7930/NCA4.2018.

40. World Bank (2020). Human Capital Project. Retrieved from: https ://www.worldbank.org/en/publication/human-capital

41. Zhao, C., B. Liu, S. Piao, X. Wang, D. B. Lobell, Y. Huang, M. Huang, Y. Yao, S. Bassu, P. Ciais, J.-L. Durand, J. Elliot, F. Ewert, I.A. Janssens, T. Li, E. Lin, Q. Liu, P. Martre, C. Müller, S. Peng, J. Peñuelas, A.C. Ruane, D. Wallach, T. Wang, D. Wu, Z. Liu, Y. Zhu, Z. Zhu, and S. Asseng (2017). Temperature increase reduces global yields of major crops in four independent estimates. PNAS, 114(35), 9326-9331. Retrieved from: https://www.pnas.org/content/ pnas/114/35/9326.full.pdf

Publisher's Note Springer Nature remains neutral with regard to jurisdictional claims in published maps and institutional affiliations. 